UDC 81'37

DOI https://doi.org/10.32838/2710-4656/2021.4-2/11

Sytniak R. M.

Horlivka Institute for Foreign Languages

of the Donbas State Pedagogical University

\title{
EVOLUTION OF THE RESEARCH OF LEXICAL CHANGES OF WORD MEANING AND REGULARITY OF SEMANTIC CHANGES
}

The article reveals the views of European linguists of the XIX-XXI centuries on the reasons and patterns of change of words lexical meaning in different languages. The attention is paid to linguistic and extra-linguistic factors that "initiate" and direct semantic changes in certain ways. The main views of linguists of the past on the issue of convenience in the lexical meaning and their meaning for modern linguistic research are outlined.

Many social and cultural changes that occur in different social environments have similar characteristics, which inevitably affects the similarities in the change of meaning of words. Human psychology cannot develop separately from changes in the environment in which this person is.

One of the most interesting problems in linguistics is the problem of identifying and classifying the factors that cause changes in word meanings. There is no doubt that with the development of society, the spheres of human activity are constantly expanding and diversifying. As a result of this process, vocabulary is also constantly changing. But the number of lexical units in any language can not satisfy the amount of new concepts that modern life provides us. Therefore, the acquisition of new meanings by one lexical unit is a very important and, without a doubt, promising way of language development. In view of this, semasiology as a science is of great interest to those who study language. But changing the meanings of words is a long-known fact, and that is why it is necessary to move from a simple statement of this phenomenon in different languages to the study of the causes and finding certain patterns in this process.

Universal laws of semantic changes, which undoubtedly would greatly facilitate research in such a realm as comparativism, attracted almost all scientists, since they are derived from the comparison of many language systems, each of which is considered more or less well-studied. As a result, there are new statements containing new knowledge, which take into account semasiological research works of the previous generations of linguists, add new ideas and use modern technologies to get new results with more precise data.

Key words: semantic meaning, linguistic and extra-linguistic factors, individual and collective psychology, social environment, regularity of semantic changes, semantic reconstruction.

Setting of the issue. No theory of language can ignore the semantic aspect of its existence. In the XXI century language researchers continue to develop key concepts of semantics, giving them a new interpretation thanks to modern information processing technologies and opportunities to obtain material from all possible corners of the world.

To this day, the attempts to compare the internal logic of the evolution of the semantic meaning of words of related and unrelated languages are not decreasing, but on the contrary, are gaining more and more scientific popularity.

The globalization of the world community leads to the spread of international words and ideas that need to be implemented in hundreds of societies and, as a consequence, languages, for effective international cooperation. The problem of identifying laws that would not only explain but also predict changes in the meanings of words is extremely relevant in modern semasiology.

Analysis of the research works and publications. The most important and influential works on the issue that are considered in the article are the works of the linguists that have formed the basis of semantic works in general and semasiology in particular. They are the researchers without which modern semantics wouldn't be the science we know today. The analyzed ideas are represented by F. Bopp, R. Rusk, J. Grimm, A. Schleicher, G. Steinthal, K. Brugman, G. Osthof, H. Paul, B. Delbruck, A. Leskin, F. I. Buslayev, O. O. Potebnya, M. M. Pokrovsky and some other influential European linguists.

The theoretical value of the article is that the main tendencies of effective scientific research of lexical 
meaning change by representatives of different generations of linguistics are considered and valued here.

The relevance of the topic is that the issues of historical semasiology retain their significance in modern linguistics and provide a basis for promising research on the lexical meaning of words. It is important to turn to the scientific heritage of linguists of the past, who made a significant contribution to the development of historical semasiology.

The aim is to reveal the views of the prominent European linguists of the XIX - early XXI century on the causes of changes in the lexical meanings of words, to identify the importance and prospects of these views for the development of modern semasiology.

The tasks to achieve this goal are:

1. To highlight the views of European researchers of the language of the XIX - early XXI century on the phenomenon of changes in the lexical meanings of words. 2. To reveal new visions of the causes of semantic changes. 3 . To prove the scientific validity of the discovery in the works of European scholars on the general patterns of semantic changes in different languages.

Main body. In the past, language researchers have identified and interpreted the causes of changes in word meanings differently. If we consider the views on this issue in the early nineteenth century, we see that well-known researchers of the language of the time, such as F. Bopp, R. Rusk, J. Grimm, in their work quite successfully identified and classified changes in word meanings, but gave little attention to their causes, giving their interpretations a philosophical character. This can be explained by the fact that along with the comparative-historical method, which became a pillar of linguistics from the end of the first quarter of the XIX century, the habits of the philosophical approach even to concretesubject aspects of linguistics were still alive. It was only through the comparative-historical method that the independent science of language emerged, separated from philosophy and history.

A. Schleicher identifies the structure of language and its functioning with the structure and functioning of organisms in nature, emphasizing the similarity of stages of language life to stages of life of any living being: "... language life is not significantly different from all other organisms - plants and animals" $[1$, p. 103]. A. Schleicher embodied these views in his "biological" concept of language. He tried to justify the possibility of natural in language, emphasizing the independence of language from the desires of the individual. The scientist chose the observation of living organisms and the laws of their lives to serve as a basis for knowledge of the historical patterns of language development. But just as an individual cannot compete with the forces of nature, so an individual cannot influence changes in language: "Schleicher proceeded from the fact that language does not depend on the individual; there are certain laws in language that the human will not be able to change" [1, p. 102].

Along with philosophical views in the early nineteenth century the foundations of psychologism in linguistics are laid. Linguistic psychology in Europe is thought to have evolved from one component of Humboldt's teaching - his subjectivism. The founder of the psychological direction in linguistics is considered to be the German linguist G. Steinthal. In particular, he pointed out the close links between linguistics and psychology, developing his theory, in which the interaction of individual speech and individual thinking came to the fore. The main thing is that the act of speech activity is not related to human social activity.

The emergence of the young grammar school in linguistics in the $70 \mathrm{~s}-80 \mathrm{~s}$ of the XIX century, associated with such names as $\mathrm{K}$. Brugman, G. Osthof, H. Paul, B. Delbruck, A. Leskin. The basis of the linguistic concept was individual psychology. Representatives of this school tried to avoid philosophy, in particular, B. Delbruck pointed out that linguistics has moved from the philosophical period to the historical. The theoretical generalization of the views of the young grammar direction was made by an outstanding representative of this school H. Paul. He considered historicism to be the only scientific principle of linguistic analysis. Considering the problem of understanding the change in the meaning of words, H. Paul distinguishes the occasional and usual meaning of words: speaks, connects with this word at the moment of its pronunciation and which, as she considers, will connect, in turn, and the listener with this word" [1, p. 123]. H. Paul considers the reason for changes in the meanings of words to be an unstable individual psychology, which causes a shift in the boundaries between the usual and occasional meanings of the word [3, p. 203]. H. Paul rejects the existence of collective psychology, rejects the existence of a common spirit or any elements of a common spirit, noting that the true reality is individual language: "Any act of linguistic creativity is always the work of the individual: [3, p. 202]. In this theory, it is the individual, not society, that 
causes changes in language and the meaning of words, beginning to understand a phenomenon differently, and it is the primary source of semantic changes in a particular language that other individuals inherit from it, spreading innovation.

F. I. Buslayev was one of the well-known linguists who paid great attention to identifying patterns in the development of language. Speaking about the relationship between language and thinking, F. I. Buslaev distinguished between two periods the oldest and latest. In ancient times, new phenomena and objects were named not due to the change of existing words, but due to the emergence of new words. In the later period, the already existing words began to acquire additional meanings. One word, thanks to our associations and all that we associate with it, can reflect much more than its basic lexical meaning: "By any word we express a general concept, which includes in its scope other concepts" [3, p. 102].

With the development of society, language develops. And the names of specific objects and phenomena acquire new meanings necessary for successful communication: "Each word first reflected the visual impression, and then moved to the symbol of a distant concept" [3, p. 9]. F. I. Buslaev was primarily engaged in grammar, but his vision of the linguistic movement from the concrete to the abstract is relevant to modern semasiological research.

An outstanding representative of Slavic linguistics O. O. Potebnya also spoke about the enrichment of existing words with new meanings as a necessity of the language-making process. He believed that the possibilities of human consciousness were limited, and that human consciousness resembled a small stage in which thoughts took turns. The only way to expand this scene, to "embrace the greatest number of phenomena and their relations" is to "reduce various phenomena to a relatively small number of signs and images" [1, p. 83]. O. O. Potebnya, realizing that languages are constantly changing due to the complexity of thinking, development of culture, social activity, speaks of a constant increase in images in human consciousness, which can not satisfy a limited number of words to denote them. This problem is solved by a change in the way of thinking: the word begins to mean not one, but many objects. O. O. Potebnya was convinced that this process is not spontaneous and the study of its laws is necessary to understand the process of language development: "In the history of language deserves general attention, of course, the study of non-sound form of words, which for all their importance have only official meaning, and the inner meaning of words, impossible, not existing without language, which is created and reproduced together with the sound appearance of words" [8, p. 5]. Considering language in its historical development, O. O. Potebnya believed that the task of linguistics in covering linguistic facts is not only to solve the question of where we are, but also where we are going. In this case, it is necessary to identify patterns in the development of language or languages in general.

The outstanding linguist M. M. Pokrovsky devoted most of his research to the discovery of general regularities that would cause such changes in the meanings of words in all languages. He played an outstanding role in the development of comparative-historical semasiology. In fact, he was the first to put forward the idea of the regularity of semantic changes, laid the scientific foundations of diachronic semasiology and developed a methodology and techniques for studying the lexical meaning of the word in its movement. The importance of all this for improving the comparative-historical method in general and etymological research, for typological and comparative study of semantic systems of different languages, for identifying general and special tools and techniques of semantic modeling and lexical-semantic way of word structure, for real linguistic study of nomination principles and the "linguistic vision" of the objective world is extremely large. V. V. Vinogradov wrote: "There is no doubt that M. M. Pokrovsky, insisting on the regularity of semantic changes and the need to study the history of the meanings of entire semantic groups or word systems depending on objective reasons, was ahead of the then European science" [7, p. 6]. With his works on historical lexicology M. M. Pokrovsky paved new ways to study the complex processes of semasiological changes in related IndoEuropean languages. Almost all comparativists of the XIX century engaged in establishing phonetic and grammatical correspondences and differences in languages that have a single root, a single speech. He significantly expanded the issues of comparative and historical research, shifting the focus to the field of vocabulary of ancient and modern languages of Europe.

The ideas of the semantic field and thematic group, semantic modeling, reconstruction of word meanings based on the modern system of language, and much more were points of M. M. Pokrovsky's research. His main works on semasiology are his master's dissertation "Semasiological research in 
the field of ancient languages" (1895) and articles "On the methods of semasiology" (1896), "Several questions in the field of semasiology" (1897), "Considerations about changes in the meaning of words" (1936). Undoubtedly, he believed in the regular development of language, that the same patterns cover different languages and it is possible to determine the conditions of coexistence of words, as well as to determine the potential of meanings inherent in these words: "Semasiological research should lead to the discovery of some syntactic laws, mandatory or those that can be applied to any language" [6, p. 36]. This problem before M. M. Pokrovsky had never been deeply considered in linguistics, and he became one of the firsts who studied semasiology as a science and laid the foundations of comparative-historical semasiology.

The development of word meanings takes place according to certain laws. This position, supported by specific linguistic facts, contrary to the views of wellknown European semasiologists, M. M. Pokrovsky put forward in the $90 \mathrm{~s}$ of the XIX century. At the time when K. Schmidt argued that there could be no question of finding laws, which would show that one or another transition of meaning must take place, explaining this impossibility by the fact that the human soul is something so complex that we are unable to predict its manifestations with regular accuracy, M. M. Pokrovsky wrote that these phenomena are natural, that we can find out the conditions of coexistence of words and establish the potential stock of meanings inherent in known words and their categories. The proposition that variations in the meaning of words are subject to certain laws, that they truthfully and accurately reflect objective changes in the lives of peoples and social groups, is not only a correct statement of what really exists in the language system - it would be very productive and promising in terms of research, leading to a diachronic study of vocabulary as a system.

The regularity of the semantic development of words, according to M. M. Pokrovsky, manifests itself in many different facts. First of all, it is manifested in the fact that in words that belong to one lexical-semantic category of any morphological category, word-formation model or semantic field (in its terminology, to a group of words united by a single "sphere of ideas"), you can usually see the same or similar semantic changes. In other words, the direction of semantic transformation of lexical units, which occurs over time, is determined by their lexical and grammatical properties, structure and belonging to a certain "thematic group".
M. M. Pokrovsky studied words in the spheres of ideas, bearing in mind certain aspects of our existence or a group of homogeneous phenomena of the external or spiritual world, trying to prove that by taking the words of one particular environment and analyzing, we can see that their semasiological history depends on certain conditions. If these conditions are similar in several languages, then the history of changes in meanings in these languages will be similar: ".. as a consequence of the same cultural and historical reason, namely: the devaluation of money, the Ukrainian words гріш, копійка, the Romans as, the French sou - have become synonymous with something insignificant" [6, p. 28].

M. M. Pokrovsky considered the comparativehistorical method to be the main means of comprehensive study of language, which is absolutely necessary: "Even a superficial comparison of the languages of the so-called Indo-European family convinces us of their mutual kinship ... visual pattern of development, as in the history of language" [6, p. 32].

At the very beginning of his research activity M. M. Pokrovsky refused to use formal logic to explain the phenomena of semasiology and recognized these phenomena as social and psychological. He considered the question of defining and explaining the relationship between the psychological and social moment to be one of the most complex and not fully disclosed in the semasiology of the time; it was necessary to determine what role these phenomena play in changing the meaning of words. M. M. Pokrovsky considered social phenomena as identical to historical ones: "We note now that historical phenomena are at the same time social phenomena" [6, p. 37].

The idea of social influence is extremely important in the XXI century where globalization of societies makes you think in the definite way; otherwise you will find yourself a social outcast.

M. M. Pokrovsky considered the psychological factor as a means by which social and historical changes are reflected in language: "Real changes that occur in a random environment cause certain changes in psychology, and hence in language, so psychology is not a semasiological factor of change, but a kind of channel where they move" [6, p. 37]. As we see, M. M. Pokrovsky did not contrast the psychological factor with the social. Apparently, it is impossible to consider either a psychological or a social factor as more or less important in the process of changing the meanings of words, because without each of them these changes simply will not happen. It follows that changes in the meaning of words also depend on 
special psychological conditions: "Words and forms of language unite in our soul, regardless of our consciousness, into different groups and categories as a result of similarity in form and content; if there are points of similarity in the categories themselves, then these categories also associate with each other, and in this case we unconsciously transfer the phenomena of one of them to another. M. M Pokrovsky emphasizes that the associations of forms, words and their categories in languages are extremely diverse and are interesting material for both linguists and psychologists.

M. M. Pokrovsky considers the social environment the starting point of semantic changes in language, and psychological perception and new interpretation of existing language patterns - the second stage in the emergence of new meanings of words: "... most of the phenomena" purely psychological (language forms of politeness and respect, taboos, offensive words) have their source in a particular social environment, and the semasiologist has no right and cannot bypass this environment, no matter which side he would approach the consideration of these phenomena" [6, p. 38]. As an example, we can take the phrase in Russian целую ручки (kissing your hands), which was used quite often in the past according to the custom of kissing the hand of ladies (this was seen as a manifestation of politeness and culture) and later replaced this physical process. In English, the phrase to throw the gauntlet means to challenge due to the ancient custom of taking off a glove and throwing at the feet of a person with whom someone intended to fight; now this phrase has acquired a figurative meaning. We see that the social environment and cultural characteristics have a significant impact on semasiological changes in different languages.

With very successful examples, M. M. Pokrovsky proves that a person's mental development and his ability to observe have always depended on the experience that a person acquires in a certain social environment: "In some cases of this kind the ability of sociological observation is obvious; such are the definitions in the Russian language, which belong to different categories of people who are drunk: the tailor настегался оr наутюжился, shoemaker настукался, musician наканифолился, footman нализался" [6, p. 39]. M. M. Pokrovsky believed that it is impossible not to pay special attention to such examples, because they most clearly prove the impact of real life on changes in language: "In such cases, we are dealing with already interconnected ideas that form unity, representations that cannot be separated.
The history of such unity is of particular interest where the influence of reality is beyond doubt" [6, p. 39].

In many nations it is very common to compare different institutions with the human body: if the language has established this general comparison, it can extend to the details of the objects being compared: so there were names for the head of the institution, members to denote its individual representatives etc.

The names of dishes in different languages can mean the appropriate time when they are used, such as Latin ab ovo usque ad mala - from snack to dessert. In English culture, oatmeal was eaten for breakfast, and the phrase after porridge still meant time - after breakfast.

In many cultures, foods were served on dishes, and over time, the word dish became attached to the meaning of the food in general. Compare, for example, English dish, Fran. plat - both of them, except for the meaning of "dish as an object similar to a plate", have meaning any addible food.

Given all these examples, we must admit that M. M. Pokrovsky was scientifically opposed to the views of most Western European semasiologists (M. Breal, K. Schmidt, O. Schroeder), who rejected the possibility of revealing historical patterns in the meaning of words. M. M. Pokrovsky, noting that semasiology as a science cannot be practiced without comparing the phenomena of one language with the phenomena of others, argued that "Despite all the difficulties and seemingly unpredictability of these phenomena ... they are regular" [6, p. 4].

Modern linguistics considers the idea of regularity of semantic change as natural and perspective. M. Urban in his article "Lexical semantic change and semantic reconstruction" draws attention to the principles of semantic change, "Thus, even though the semantic history of each single word is different, there is nevertheless a typical line of development on a more general level of description" [10, p. 378].

E. Traugott and R. Dasher absolutely naturally point out the importance of changes in extra-linguistic world. "They recur so often and across totally unrelated languages is, we argue, intrinsically bound up with the cognitive and communicative processes by which pragmatic meanings come to be conventionalized and reanalyzed as semantic polysemies" [9, p. 1-2]. Of course, international communication is now on top of activity and to provide different societies effective means of communication we need similar way of semantic mind.

Results and suggestions. The study of research in linguistic historiography highlights key points in 
the development of views of European linguists on changes in the semantics of the word in its diachronic movement in European linguistics of the XIX - early XXI century.

Thanks to new technologies the scholars are enabled to compare languages, cultures and social structures of a considerate number of countries increasing scientific value of the research. However, one can't but accept the fundamental ideas of the language researchers of the past who built the basement for the theories that are actively being developed by modern linguistics.

\section{References:}

1. Березин Ф.М. История лингвистических учений. Москва : Высшая школа, 1975. 304 с.

2. Буслаев Ф. И. Историческая грамматика русского языка. Москва : Учпедгиз, 1959. 623 с.

3. Звегинцев В.А. История языкознания XIX-XX веков в очерках и извлечениях. Ч. 1. Москва : Просвещение, 1964. 466 с.

4. Бодуєн де Куртенэ И. А. Избранные труды по общему языкознанию. Т. 2. Москва : Изд-во АН CCCP, 1963. $391 \mathrm{c}$.

5. Лоя Я.В. История лингвистических учений. Москва : Высшая школа, 1968. 308 с.

6. Покровский М.М. Избранные работы по языкознанию. Москва : АН СССР, 1959. 382 с.

7. Покровский М. М. Семасиологические исследования в области древних языков. 2-е изд. Москва : 2006. $136 \mathrm{c}$.

8. Потебня А. А. Из записок по русской грамматике. Москва : Просвещение, 1968. Т. 3. 552 с.

9. Traugott E. C., Dasher R. B. Regularity in semantic change. Cambridge : Cambridge University Press. $2001.341 \mathrm{p}$.

10. Urban M. Lexical semantic change and semantic reconstruction from: The Routledge Handbook of Historical Linguistics Routledge. 2014. 392 p.

\section{СИТНЯК Р. М. ЕВОЛЮЦІЯ ДОСЛІДЖЕНЬ ЛЕКСИЧНОГО ЗНАЧЕННЯ СЛІВ ТА ЗАКОНОМІРНОСТІ СЕМАНТИЧНИХ ЗМІН}

У статті виявлені погляди європейських мовознавців XIX-XXI століття щодо причин $і$ закономірностей зміни лексичного значення словами різних мов. Приділено увагу лінгвістичним та екстралінгвістичним чинникам, які «ініціюють» та скеровують семантичні зміни певними шллхами. Окреслено основні погляди мовознавців минулого на питання зрушень у лексичному значенні та їхню значущість для сучасних лінгвістичних досліджень.

Більшість сочіальних і культурних змін, які відбуваються в різних соиіальних середовищах, мають подібні характеристики, щуо неминуче впливає на схожість у зміні значення слів. Психологія людини не може розвиватися окремо від змін середовища, в якому знаходиться ия людина.

Однією з найцікавіших проблем мовознавства є проблема виявлення та класифікації факторів, що спричинюють зміни у значеннях слів. Немає сумніву, щз з розвитком суспільства сфери людської діяльності постійно розиирюються та урізноманітнюються. Внаслідок иьього процесу словниковий запас також постійно змінюється. Але кількість лексичних одиниць у будь-якій мові не може задовольнити кількість нових понять, які нам постачає сучасне жсття. Тому набуття нових значень однією лексичною одиницею є дуже важливим $i$, без сумніву, перспективним способом розвитку мови. Зважаючи на це, семасіологія як наука становить значний інтерес для тих, хто вивчає мову. Але зміна значень слів - ие давно відомий факт, тому необхідно перейти від простого викладу иього явища на різних мовах до вивчення причин і пошуку певних закономірностей у иьому процесі.

Універсальні закони семантичних змін, які, безсумнівно, значно полегшили би дослідження в такій сфері, як компаративізм, привернули увагу майже всіх науковців, оскільки иі зміни походять від порівняння багатьох мовних систем, кожна з яких вважається більш-мени добре вивченою. Внаслідок иього з'являються нові твердження, що містять нові знання, котрі враховують семасіологічні дослідницькі роботи попередніх поколінь лінгвістів, додаючи нові ідеї та використовуючи сучасні технології задля отримання нових, більш точних результатів.

Ключові слова: семантичне значення, лінгвістичні та екстралінгвістичні чинники, індивідуальна та колективна психологія, сочіальне оточення, закономірність семантичних змін, семантична реконструкиія. 